\title{
The Potential for Monopoly Rents from Etosha National Park, Namibia
}

\author{
Janet Ågren, Carita Nyyssölä and Jesper Stage \\ Department of Economics, Umeå University, Sweden
}

\begin{abstract}
This paper reports on a survey carried out among visitors to Etosha, Namibia, in May 2002. We use the contingent valuation method to estimate foreign tourists' willingness to pay for visiting the park. We find that the Namibian government could raise park fees substantially and increase profits from foreign tourists by approximately $\mathrm{N} \$ 2,3$ million per year. If fees were raised in collusion with other governments, in order to avoid competition between countries in the region, profits could presumably be increased even further. However, the survey used to collect data on tourists' willingness to pay also indicated dissatisfaction with current management of in-park resorts, and improved management of these resorts would probably be crucial for the success of any new tariff scheme.
\end{abstract}

JEL H21, H42, L12, L83, Q21

\section{INTRODUCTION}

African wildlife in its natural habitats is a resource which is unique to the African continent and, largely, to the national parks on this continent. This means that African wildlife tourism is a market with natural barriers to entry and, hence, with potential monopoly rents to be earned by governments through suitable pricing or taxation policies.

International wildlife tourism accounts for considerable fractions of foreign exchange earnings, and of GDP, in many African countries (see, for instance, Bird, 1992, or Cleverdon, 2002). However, the issue of optimal pricing and taxation arrangements for international tourism has still not been properly analysed in many countries. Prices are frequently set at rates that are intended to be "competitive" in comparison to other tourist destinations, in order to maximise the number of tourists. This sometimes entails explicit or implicit support to the tourism industry in the shape of subsidies or tax breaks. Even where this is not the case, price policies frequently only aim at recovering the financial costs associated with operating the parks. 
However, when the customers of a monopolistic industry are mainly foreigners, financial cost recovery should not be seen as the appropriate goal. Rather, the government's goal should be to maximise the monopoly rents earned from the industry.

This paper studies the opportunities for increasing profits to Namibian society from the Etosha National Park. Etosha is one of the largest national parks in Southern Africa with a unique diversity of flora and fauna, and has approximately 150000 visitors annually, most of whom are foreign tourists. The park fee for foreign visitors is currently less than a percent of the visitors' total cost for visiting the park, so that a large part of their willingness to pay for park visits is, in all likelihood, either appropriated by other agents or accruing to the tourists themselves in the form of increased consumer surplus.

There are several options available for increasing government profits from Etosha. The obvious option would of course be to raise fees generally. A further option could be to use price discrimination between different tourist groups; this is already used to some extent, in that Namibian visitors pay only half the fees that foreign visitors do, but if foreign tourist groups of different origin have different willingness to pay one might also envisage setting different fees for different groups on the basis of origin. Since there is a risk that higher fees can lead to a loss of visitors to other parks in the region, an additional option might be to increase park fees in collusion with other governments, i.e. form a cartel in order to increase overall revenue from parks.

This paper therefore studies tourists' willingness to pay for visiting Etosha and the potential for increased profits through higher fees. A stated preference $(\mathrm{CVM})$ approach is used to determine what the profit maximising fees would be if fees were set separately for two different groups, visitors from other African countries and visitors from non-African countries. Other subdivisions could have been made, but this categorisation would be relatively easy to enforce, and if agreements on tariff setting were to be made with other African countries it is likely that this would include lower tariffs for residents of the countries involved in the agreement. It is therefore of interest to study non-African tourists, who would not be included in a pricing agreement, separately from the tourists from African countries.

\section{TOURISM IN ETOSHA}

Etosha is the oldest and most visited national park in Namibia. The park lies in the north of Namibia with a size of 22270 square kilometres. In 1907 Governor von Lindequist established the park with the aim of preserving and protecting 
wild animals. When the park was first established it covered approximately 100000 square kilometres, running all the way to the Atlantic Ocean. In 1964, the park obtained its present size, and by 1973 a fence had been placed around Etosha in order to stop migration patterns and disease spreading among the animals.

Etosha is Namibia's main tourist attraction with visitors coming from all over the world. The tourists arrive either at the Andersson gate in the south or at the von Lindequist gate in the east. When arriving at the gate the tourists have to register in order to get their park permit. The daily fee is currently N\$ 15 for Namibian residents while foreigners pay $\mathrm{N} \$ 30$ (Namibia is part of the CMA zone and $1 \mathrm{~N} \$=1 \mathrm{ZAR})$. In addition to this, a vehicle fee of $\mathrm{N} \$ 10$ must be paid once per entry.

The main attraction in Etosha is the diversity and large populations of animals. The 1995 aerial census found that the park was home to more than 40000 big animals (Auer, 1998) and more than 114 different mammal species, of which the most famous are lions and elephants. Other animals that can be spotted in the park include black rhino, zebra, springbok, impalas, cheetah, and leopards. Waterholes have been set up near the tourist roads, to make it easier for tourists to spot animals. Another reason for the park's popularity is the varied landscape. The vegetation changes from savannah to steppe and into the dry pan. Etosha means "Great White Place", a name which refers to the big salt pan in the east of the park; this salt pan covers over 5000 square kilometres and is partially filled with water in the rainy season. The park is host to more than 340 bird species and during the rainy season many migratory birds, such as flamingos, come here to breed.

There are three rest camps in Etosha: Okaukuejo, Halali and Namutoni. Okaukuejo is the oldest and most popular, with a water hole that can be visited during the day, and also at night when it is floodlit. Namutoni rest camp is situated in the northeast and the main building, and accommodation, is the rebuilt Fort Namutoni. Halali is the smallest rest camp and is located between Okaukuejo and Namutoni. Tourists who do not wish to spend the night in the park have other options just outside the park, where several private lodges can be found.

The Ministry of Environment and Tourism (MET) formerly managed the rest camps in Etosha. However, in 1999 the management of the park was divided between the MET and the government owned company: Namibian Wildlife Resorts (NWR). NWR now administers the tourism facilities and the accommodation, whilst MET handles the maintenance and management of the park as well as wildlife supervision. NWR is intended to function as a normal 
firm but has received repeated grants and subsidies from the government; although some of this could be seen as covering the cost of reduced accommodation fees for Namibian residents (which is more appropriately paid by the government than by a firm) these grants effectively entail giving government subsidies to foreign tourists, and the intent is that these subsidies will disappear as NWR becomes more fully operational.

In Namibia, part of the tax on petrol and diesel is earmarked for road maintenance and the revenue from this tax goes to the Roads Authority, an independent government entity which is responsible for the country's roads. However, maintenance of tourist roads within Etosha, which should in principle also be funded through this tax, is still handled by MET as part of general government operation costs for the park. Despite the considerable tourist traffic on the park roads, they are therefore still gravel only and the lack of general government funds for park maintenance have led to insufficient road maintenance, so that the roads have deteriorated.

Visitor numbers have increased substantially from 1990 onwards, putting increased pressure on facilities as well as, potentially, increased pressure on the ecosystems of the park. However, a study recently commissioned by the MET (Tarr et al., 2000) found no evidence of ecosystem damage arising from tourism, indicating that there is still room for increasing tourist numbers without damaging the environment of the park.

\section{THEORY}

When setting park fees for national parks, several factors must be taken into consideration. It is important to take into account, not only financial, but also social and economic considerations. When setting fees for domestic tourists, not only government profits from park fees should be considered, but also the consumer surplus for the tourists, since this will be part of the overall social welfare generated by the park. However, when setting park fees for foreign tourists, issues of consumer surplus can be ignored, since any consumer surplus will in any case accrue to (usually very affluent) foreign tourists rather than to members of Namibian society.

This implies that the pricing between foreigners and domestic residents should differ, perhaps substantially. The government should try to maximise its profit from the foreigners like an ordinary monopolistic firm; in other words, set fees so that the marginal cost equals the marginal revenue rather than the fee. For domestic tourists, on the other hand, fees should be set equal to the marginal cost. If monopoly prices were to be used for domestic visitors, a dead weight 
loss for the domestic consumers would be created since their consumer surplus would be lower. Hence, the optimal park fee for the country residents is where marginal cost equals the demand for country residents to visit the park (Carlton \& Perloff, 1999).

Price discrimination, for instance between different tourist groups, is one possible course of action to make parks more profitable. The fees that should be charged are decided by the price elasticities for the different groups. If demand from a group is inelastic, a high fee can be charged, and vice versa if the demand is elastic. This implies that a tourist group with a high elasticity should be charged a lower fee than a group with an inelastic demand. Fees for a specific group should be set so that the marginal revenue from that group is equal to the marginal cost caused by visitors belonging to that group.

If there exist social or environmental costs in addition to the financial costs, economic marginal costs are higher than the financial marginal costs, and the park fees (both for foreigners and domestic tourists) should be set higher than if there were no additional social costs. The most common tourist related externalities in national parks are congestion, eco-damage and wildlife disturbance. The first problem implies that when too many tourists are visiting the park, tourists' enjoyment, and hence their willingness to pay, may decrease. Congestion can also disturb the wildlife; this may reduce tourists' enjoyment of their visit further (Shah, 1995).

Eco-damage is present in Etosha and the main source of damage is the tourist roads, which have a negative effect on flora and fauna. The gravel roads create a lot of dust when people are using them. This, combined with limited maintenance of the roads, increases the dust generation and worsens the situation for the vegetation and animals close to the roads. It is difficult to calculate the exact economic cost of this damage. However, since the revenue from the petrol taxes paid by the tourists would be enough to pay for tar roads, it is reasonable to assume that this cost is already internalised and that the main problem is that revenue from this tax is currently not going to the agency responsible for the park roads.

It is also difficult to value wildlife disturbance in the park. Many tourists drive off the roads or drive too fast, which in some cases can lead to road kills. However, there are no available data on the number of road kills that occur every year. Again, this cost could be reduced by road bumps and by other traffic obstacles making it more difficult to leave the roads, and this could in principle also be paid for through the petrol tax revenue generated by the tourists. 


\section{DATA}

In order to provide data for the study, a survey was carried out at the Andersson gate during three weeks in May 2002. During the survey period most tourists arrived through this gate. A total of 500 questionnaires were distributed to the incoming tourists. The questionnaires were handed to tourists when they were entering the park, and these questionnaires could then be handed in either at the tourist centre in Okaukuejo camp or at one of the gates when leaving. Distributing the questionnaires was fairly straightforward since the tourists had to register at the gate both when entering and leaving the park. 275 questionnaires were completed, giving a response rate of 55 percent. In general, the respondents did not neglect to answer any of the questions and often gave very detailed comments. Hence, the data provided a good basis for analysis.

The costs of operating the park are mainly divided between the management and maintenance departments. In 2001 the management department spent approximately $\mathrm{N} \$ 3,9$ million in order to perform its duties. The department's main expenditures consist of salaries, including overtime and vehicle costs. Maintenance has four major costs: construction, water supply, fencing and tourist roads. This sums up to approximately $\mathrm{N} \$ 5,3$ million. The total cost in year 2001 was thus approximately $\mathrm{N} \$ 9,2$ million.

However, the cost of maintaining tourist roads should not be included in the total cost used to determine park fees, since costs for road maintenance are in principle already paid for through the petrol tax. Although this cost is part of the park budget, it should therefore be considered as being internalised through other taxes and not as one of the costs which need to be financed through the park fees. Excluding road maintenance from the operational costs leaves a total cost of N\$ 8,1 million.

As noted, the operation of the park resorts is now in the hands of a government company which, presumably, attempts to maximise its profits by setting appropriate prices. This simplifies the analysis, since most of the costs which vary with the tourist numbers are now the responsibility of the NWR. Thus, the MET expenses for the park can be seen as more or less fixed, giving a financial marginal cost approximately equal to zero.

There is no congestion in Etosha, and the eco-damage costs are in principle already internalised through petrol taxes (although allocated to the wrong government agency). This means that there is no need to internalise social and environmental marginal costs through the park fees. Consequently, when calculating optimal fees and tourist numbers, it has been assumed that the marginal cost of an additional tourist is approximately equivalent to zero. 


\section{TOURIST CHARACTERISTICS}

\section{Table 1 Tourist Profile}

\begin{tabular}{|c|c|}
\hline Parameter & Value \\
\hline Namibia & 30,5 percent \\
\hline Other Africans & 17,2 percent \\
\hline Overseas & 52,3 percent \\
\hline Mean age & 44,1 years \\
\hline Sex: Male & 63,1 percent \\
\hline Mean group size & 3,83 persons \\
\hline Mean trip days & 16,96 days \\
\hline Mean days spent in Etosha & 3,19 days \\
\hline Mode of transport: Car & 91,3 percent \\
\hline Type of accommodation: Bungalow & 54,6 percent \\
\hline Camping & 28,9 percent \\
\hline Mean income: Namibia & $\mathrm{N} \$ 13000$ \\
\hline Other Africans & $\mathrm{N} \$ 20000$ \\
\hline Overseas & $\mathrm{N} \$ 40000$ \\
\hline
\end{tabular}

In Table 1 the general features of the respondents are illustrated. Respondents from 16 different countries were included; 30,5 percent were Namibian residents. The two largest foreign tourist groups were from Germany $(28,2$ percent) and South Africa (16,9 percent). In total, more than half of the tourists (52,3 percent) answering the survey were from non-African countries. The average respondent was a 44,1 year old male.

During the visit in Etosha 54,6 percent of the respondents stayed in bungalows, 28,9 percent were camping, 14,3 percent stayed in lodges outside the park and 2,2 percent stayed in other accommodation, for example luxury suites. The overall experience for the respondents was mostly described as very good or good ( 84,3 percent) despite the fact that 62,9 percent did not see all the animals that they had hoped to see. When asked about the tourist and vehicle numbers most respondents felt that the numbers were just right. Most tourists, 93,6 percent, found environmental issues to be very important and a total of 97,4 percent considered it to be very important to preserve endangered species.

One frequent problem in surveys is that respondents are often reluctant to answer questions about income, but the response rate for this question proved to be over 85 percent. The mean income for Namibian residents was approximately N\$ 13000 per month. For other African residents the average monthly income 
was slightly higher: $N \$ 20000$, while the overseas tourists had a substantially higher average monthly income: N\$ 40000 per month.

The respondents had the opportunity to comment on the questionnaire and to express their opinion about their experience in the park. In one of the questions they were asked to state why they chose to visit Etosha. The most common replies were that the park hosted a unique diversity of animals and nature in its natural habitat. Other reasons were: its size, as it is one of the largest game parks in Namibia, its reputation, and the location of the park. In other words, it was quite important for the tourists that the park was easily accessible and that it was well known. Other factors that were of importance was the tranquillity in the park and camps, and that the park visit was considered rather inexpensive.

Many remarks were made about the camps, especially about the maintenance of the accommodation and the facilities, which were in a poor condition and in need of improvement. There were also comments about the inadequate assortment and service received in the shops, restaurants and tourist information centre. Moreover, responses to a question about waiting time indicated that the tourists mainly had to wait at the rest camps and not at the gates. Another issue was the loud noise made at the waterholes, and from the staff quarters that the tourists perceived as disturbing. Furthermore, a common complaint was that most drivers were travelling too fast in the park and that the roads were in need of attention. Several suggestions for improvements were made, for instance, information boards about the waterholes, animals, and warning signs for jackals. It was also desirable to have professional guides and night drives.

Despite many complaints made about the state of the camps, a number of tourists were satisfied with the present camping facilities and accommodation. Numerous positive comments were made of the park and the roads. Some people were very impressed with the beautiful views and accessible waterholes. Finally, many respondents considered the park personnel and rangers to be very friendly and helpful.

Questions about the vehicle and tourist numbers were included in the questionnaire to examine if there is any crowding in Etosha. Most respondents, 87,7 percent, considered the tourist number to be just right. Very few (only 9,7 percent) believed there were too many tourists in the park. The same question was asked about the vehicle numbers, which gave similar replies. 89,1 percent of the respondents felt that the number of vehicles were just right, while few $(8,3$ percent) thought there were too many. Consequently, it is reasonable to assume that congestion is not perceived as a problem by most tourists, confirming the earlier findings made by Tarr et al. (2000). 
70,8 percent of the respondents stated that there were no substitutes to the park, and an additional 15,7 percent of the respondents were not aware of any alternatives. The tourists who considered there to be substitutes to Etosha were only 13,5 percent. The alternative destinations suggested by these tourists were rather diverse and they did not always refer to a meaningful alternative, which may be because the respondents did not fully understand the question. The suggested alternatives were, for instance, a private lodge outside the park or nearby towns. These destinations cannot be referred to as substitutes to Etosha as they are not able to offer the same experience.

In order to estimate demand curves for different groups, several questions were used in the questionnaire that considered the respondents' maximum willingness to pay. In one of the questions, the respondents had to answer how they felt about the present park fees. On average, both African and non-African tourists found the park fee to be appropriate at its present level. African residents' average willingness to pay was given as $\mathrm{N} \$ 40$ with a median of $\mathrm{N} \$ 30$, which is the present level. The non-African tourists' willingness to pay was, as might perhaps have been expected, higher than this; the mean value was $\mathrm{N} \$ 74$ and the median was N\$ 50. The mean WTP for tourists staying in lodges outside the park was $\mathrm{N} \$ 76$, compared to $\mathrm{N} \$ 54$ for the tourists staying within the park, but since only 33 respondents were staying in lodges this group was too small to draw any definite conclusions.

Almost all respondents, 91,4 percent, thought that the trip was worth the money that they had spent. A follow up question was asked, where the respondents had to specify a park fee that would prevent them from returning. The mean level stated was 1,5 times the present level for other Africans and 3 for non-Africans, which was fairly close to the results from the other WTP questions. Finally, the respondents were asked if they would recommend a visit to the park to other people in their home country, and 98,7 percent answered that they would. This suggests that the tourists were generally satisfied with their trip to Etosha and that their willingness to pay is higher than what they are presently paying.

There is a risk that those answering were the most keen about nature conservation (and thus with the highest WTP) and that they were not representative for the entire group. Nevertheless, the response rate for the survey was quite high, 55 percent, and consequently the results for the study are believed to be accurate. There is also a risk that since the survey was carried out in May 2002, in the middle of a worldwide recession, visitors may have been more cost conscious than usual and stated lower WTPs than they would have done under more favourable economic conditions. The WTP values used in the analysis could thus, potentially, be understated. If this is the case the true 
demand curves (and, hence, the profit maximising tariffs) for the two groups will be higher than suggested by our analysis.

\section{RESULTS}

Restricted least squares were used to determine the demand functions for the two groups of foreign tourists, with the willingness to pay as the dependent variable, with the response rates for the different willingness to pay levels as the predictor, and with the visitor number constrained to the current level at the present park fee level.

The visitor number for 2000 has been produced from the entrance books for Etosha, where tourists need to register on entry. However, data were not available for three months and for these three months the average monthly visitor number was used to add up to a full year. The visitor number used for 2000 is therefore not entirely correct, but can nonetheless give a reasonable approximation.

Table 2 Results of estimating a constrained log-log demand function for tourists from African countries

\begin{tabular}{|l|c|c|c|}
\hline & Coeff. & Std. Err. & t \\
\hline $\ln (\mathrm{q})$ & -.7729676 & .12488 & -6.190 \\
\hline Const. & 11.13068 & 1.2488 & 8.913 \\
\hline
\end{tabular}

Table 3 Results of estimating a constrained semilog demand function for tourists from African countries

\begin{tabular}{|l|c|c|c|}
\hline & Coeff. & Std. Err. & t \\
\hline $\mathrm{q}$ & -.0000542 & $7.13 \mathrm{e}-06$ & -7.606 \\
\hline Const. & 5.185569 & .2346277 & 22.101 \\
\hline
\end{tabular}

Table 4 Results of estimating a constrained linear demand function for tourists from African countries

\begin{tabular}{|l|c|c|c|}
\hline & Coeff. & Std. Err. & t \\
\hline $\mathrm{q}$ & -.0028635 & .0004749 & -6.030 \\
\hline Const. & 124.2162 & 15.62466 & 7.950 \\
\hline
\end{tabular}

For residents of African countries, three econometric specifications were estimated - linear, semi-log and $\log -\log$, with the constraint that at the fee of 
N\$30 the visitor number should equal the current level of 32902 (Tables 2 through 4). The linear model had the least satisfactory adjusted $r^{2}$ of 74,2 percent, while the log-log model had an adjusted $r^{2}$ of 79,2 percent. The best fit for African residents was the log-linear demand function with an adjusted $r^{2}$ of 85,2 percent. The demand function estimated was $Q_{a f}=\frac{5,185569-\ln P}{5,42 \times 10^{-05}}$, where $Q_{a f}$ is the number of visitors from African countries and $P$ is the park fee to the park. Based on this demand function, the marginal revenue $M R_{a f}$ can be calculated as $M R_{a f}=e^{5,185569-5,42 \times 10^{-05} Q_{a f}}\left(1-5,42 \times 10^{-05} Q_{a f}\right)$.

The profit maximising park fee for African residents is $\mathrm{N} \$ 66$, given the assumption that the marginal cost equals zero. At this park fee there would be 18 375 visitors from other African countries, as compared with the present number of 32 902, but generating a total revenue of $\mathrm{N} \$ 4,5$ million (4,3 million in park fees and 200,000 in vehicle fees) rather than the present level of N\$3,8 million $(3,5$ million +300000$)$, provided that the average number of days spent in Etosha by African tourists remained at 3,54.

Table 5 Results of estimating a constrained log-log demand function for tourists from non-African countries

\begin{tabular}{|l|c|c|c|}
\hline & Coeff. & Std. Err. & t \\
\hline $\ln (\mathrm{q})$ & -.6103584 & .0359202 & -16.992 \\
\hline Const. & 10.27667 & .40464 & 25.397 \\
\hline
\end{tabular}

Table 6 Results of estimating a constrained semilog demand function for tourists from non-African countries

\begin{tabular}{|l|c|c|c|}
\hline & Coeff. & Std. Err. & t \\
\hline $\mathrm{q}$ & -.0000237 & $1.22 \mathrm{e}-06$ & -19.455 \\
\hline Const. & 5.247447 & .0949082 & 55.290 \\
\hline
\end{tabular}

Table 7 Results of estimating a constrained linear demand function for tourists from non-African countries

\begin{tabular}{|l|c|c|c|}
\hline & Coeff. & Std. Err. & t \\
\hline $\mathrm{q}$ & -.0019584 & .0002405 & -8.142 \\
\hline Const. & 182.8317 & 18.77033 & 9.740 \\
\hline
\end{tabular}

For non-Africans the same three specifications (linear, semi-log and log-log) were estimated using restricted linear squares, with the constraint that at the fee of 
$\mathrm{N} \$ 30$ the visitor number should equal 78040 (Tables 5 through 7). The best fit was given by the log-linear specification, with an adjusted $r^{2}$ of 90,7. (The linear model produced an adjusted $r^{2}$ of only 32,7 , while the $\log$-log model had a higher adjusted $r^{2}$ of 88 percent.) The estimated demand function was thus $Q_{n a f}=\frac{5,247447-\ell n P}{2,37 \times 10^{-05}}$, where $Q_{n a f}$ is the number of visitors from non-African countries and $P$ the park fee paid by these tourists. The marginal revenue function given by this demand function can be written as $M R_{\text {naf }}=e^{5,247447-2,37 \times 10^{-55} Q_{n f}}\left(1-2,37 \times 10^{-05} Q_{n a f}\right)$.

The profit maximising tariff for non-African tourists, $\mathrm{N} \$ 70$, is only slightly higher than for African tourists. The visitor number at this tariff level is estimated as 42150 visitors from overseas, compared to the current number of 78 040. Assuming that the mean average of days spent in Etosha by nonAfricans remained at 3,23, this would increase the total revenue from nonAfrican tourists from the present level of $\mathrm{N} \$ 8,3$ million (7,5 million in park fees and 800,000 in vehicle fees) to 9,9 million (9,5 million in park fees and 400,000 in vehicle fees).

\section{CONCLUSION}

This study suggests that it could be beneficial for the Namibian government to modify the present park-pricing scheme for Etosha National Park. The results imply that increasing the park fee to $\mathrm{N} \$ 66$ for visitors from other African countries and $\mathrm{N} \$ 70$ for non-Africans would increase total profits from foreign tourists from $\mathrm{N} \$ 12,1$ million to 14,4 million. The difference between the profit maximising park fees for African and non-African visitors is small, and as long as there is no agreement on tariff setting with other African governments the administrative problems associated with having two different fees may be enough to warrant maintaining a joint fee for the two groups.

Using higher fees to generate more revenue for the government would enable numerous opportunities. For instance, more funding could be invested in conservation of endangered species and the protection of the environment. It would also be possible to improve the conditions in the park. This should increase long-term demand for visiting the park, and in turn increase revenue further.

Higher park fees in Etosha would presumably induce at least some foreign tourists to go elsewhere for their wildlife viewing. It would therefore be desirable for governments in the region to cooperate in exchanging experiences 
from tariff setting and, preferably, setting tariffs jointly in order to reduce competition and increase overall profits from foreign tourism.

Most of the environmental costs caused by tourists are already internalised through the petrol tax, but the revenue from this tax is not currently used for park maintenance. It would therefore be desirable either to use petrol tax revenue to finance the road maintenance part of the park budget or to transfer responsibility for park roads to the government agency responsible for maintenance of other Namibian roads; this would provide a closer link between the costs being internalised and the tax used to internalise them, and would make it easier to finance tar roads (which would decrease the ecosystem pressure substantially).

In any case, the pressure on the park ecosystems, and any other social costs associated with park tourism, would be reduced by the tariffs suggested here, since the visitation rate for the foreign tourists would almost be reduced by half. If additional social or environmental costs are identified by future research this would imply that the tariffs should be set even higher than advocated here; our figures, which are substantially higher than the present day fees, should therefore be seen as lower rather than upper bounds for the tariffs.

Many tourists remarked on the condition of the NWR rest camps, and their main concern was that the camps were in need of improvement. It is important for the Government that both MET and NWR operations in the park function smoothly. If the NWR management does not function well, this is likely to decrease the chance of success of a new tariff regime. If the park fees were to be increased without improvements in NWR management there is a risk of declining demand, which would affect both MET and NWR. On the other hand, if NWR management were to be improved, the revenue generated might be even higher than estimated in this study, and visitor numbers might increase beyond the estimated numbers.

Etosha National Park is a great resource and has the potential of generating more income for the Namibian Government. By managing the park resorts better, creating closer links between environmental costs and the taxes used to offset these costs, and setting more appropriate park fees, there is an opportunity that both the Namibian Government and Namibian society as a whole can benefit even more than is presently the case. 


\section{ACKNOWLEDGMENTS}

Financial support from the Swedish International Development Co-operation Agency (Sida) is gratefully acknowledged. The authors are indebted to Jon Barnes, Ben Beytell, Shayne Kötting, as well as many others at the Ministry of Environment and Tourism in Namibia for help with the study. We are also grateful to Åsa Linder and Mia Wikström at the Department of Economics, Umeå University, as well as to an anonymous referee, for constructive comments on earlier versions of this paper. All responsibility for any errors is of course ours only. The conclusions and suggestions in this paper should be seen as our personal conclusions and suggestions only, and not as those of the abovementioned individuals or organisations.

\section{REFERENCES}

1 AUER, C. (1998) "Water availability and chemical water quality as important factors for sustainable wildlife management in the Etosha National Park and for domestic stock in farming areas of Namibia", Research Discussion Paper No 26. Directorate of Environmental Affairs, Ministry of Environment and Tourism, Windhoek.

2 BIRD, R.M. (1992) "Taxing tourism in developing countries", World Development, 20(8): 1145-58.

3 CARLTON, D.W. \& PERLOFF, J.M. (1999) Modern Industrial Organization (3rd ed.) MA: Addison-Wesley Longman: Reading.

4 CLEVERDON, R.G. (2002) "Tourism development in the SADC region: The opportunities and challenges", Development Southern Africa, 19(1): 7-28.

5 SHAH, A. (1995) The Economics of Third World National Parks: Issues of Tourism and Environmental Management, Edward Elgar: Aldershot, UK.

6 TARR, P., NAKANUKU, L., NGHITILA, T., BERRY, H. \& HIPONDOKA, M. (2000) "An assessment of the negative impacts of tourism in Etosha and Sossusvlei/Sesriem", Mimeo, Ministry of Environment and Tourism, Windhoek, Namibia. 